\title{
A THINK-ALOUD PROTOCOLS AS A COGNITIVE STRATEGY TO INCREASE STUDENTS' WRITING NARRATIVE SKILL AT EFL CLASSROOM
}

\author{
by \\ Purwo Trapsilo \\ purwotrapsilo@yahoo.com
}

STKIP KUMALA Metro Lampung Indonesia

\begin{abstract}
:
The purpose of this study was twofold: its first aim was to know whether any differences of think-aloud potocols to develop writing narrative skill; second, to know whether which one is more effective to develop students' writing narrative skill by using think-aloud protocols and traditional method. Students randomly assigned to an experimental and a control group. Treatment had three stages. In Stage 1, students were asked to write about a topic. In Stage 2, students in the experimental group studied a model essay about that writing task and they had think-aloud protocol about those aspects of language that they noticed in the model essays. However in the control group, students studied model essays for themselves and they did not have think-aloud part. In Stage 3, students were asked to rewrite the writing task. The students in the experimental group showed that they got higher score in writing narrative by using think-aloud protocols than the control group. Furthermore, in the post test, experimental group outperformed the control group. The findings of the study suggest that thinking-aloud could be a good strategy for improving writing narrative performance.
\end{abstract}

Keywords: Think-aloud protocols, Writing Narrative skill, EFL

Nowadays, English language is very important for people. English language is an international language, it means that English language very important to us. Speaking, listening, writing, reading are four skills which are very important, if you want to increase your knowledge in English lesson. One of them is writing. Some of teachers, especially English teacher in Indonesia, try to use the various techniques or strategies to make their students understand. It is widely known that writing is one of the important skills in English. It means that writing skill is an important ability which should be mastered in English. In this case, narrative text is a text which bring the readers to be entertained. Besides, the students can improve their writing narrative performance well when teachers can 
provide a great learning class. On the other hand, they need to practice their writing narrative in a great way. Moreover, although applied linguists have come to recognize the importance of writing in its own right as well as its complexity, writing remains one of the least well-understood, if not misunderstood, subjects in applied linguistics in general (Silva and Matsuda, 2002). Narrative is representation of a series of events connected in a temporal and causal way. Films, plays, comic strips, novels, newsreels, chronicles and treatises of geological history are all narratives in this widest sense. Narratives can be constructed using a wide variety of semiotic media: written or spoken language, images, gestures and acting.

Think-aloud protocols involve the verbalization of thinking during reading, problem solving, or other cognitive tasks (Oster, 2001; Schunk, 2004). Participants might verbalize commentary, questions, generating hypotheses, or drawing conclusions. Such a method of data collection, known as "thinking aloud", has been imported from the cognitive sciences and applied to translation research. Thus, think-aloud may serve as both an instructional tool and method of assessment. Significant research has focused on explicit efforts to understand the thinking process and the comprehension of text (Davey, 1983; Bereiter and Bird, 1985). Utilizing think-alouds in such a manner involves teacher modeling, teacher-student interaction, and finally, the independent use by the student. However, Beck and Kucan (1997) point out that much of the research does not offer specific examples of this process. Limited research has been done with think-alouds and science instruction.

Martin-Hansen and Johnson (2006) present an example of modeling a think-aloud during text reading. However, the authors assert that once this process is modeled, student will independently use this process during science text reading and scientific inquiry. Although think-alouds provide scaffolding for students as they engage in higher order thinking (Oster, 2001), a full assessment of their thinking process is limited to what is openly shared in the verbal exchange. Many attempts have been made in the literature to measure learning strategies in various contexts with different data gathering methods (Schellings, 2011; Scott, 2008). Here, data are gathered as learners are asked to verbalize all their ongoing actions 
and thoughts (Scott, 2008). In this way, text processing and learning activities are directly revealed without delay and are expressed in students' own words. Afterwards, the verbalizations are transcribed by the researcher into a think-aloud protocols.

Think-aloud protocols are often used in revealing the strategic decisions learners use in learning and performing tasks in a second language. Two common types of think-aloud procedures have been used, concurrent and retrospective think-aloud (Kuusela and Paul, 2000). The participant typically either voices aloud thoughts, feelings, and reasoning as the primary learning activity is going on, or stops the primary task every now and then, usually at the prompt of a visual, acoustic or semantic reminder, so that s/he can tell the researcher what has been going on in his/her mind. Retrospective think-aloud happens at the end of a learning task, and is meant to collect the participant's thinking and reasoning processes while they are still in the short-term memory of the learner.

This article tries to provide a more comprehensive look at student learning process. A better understanding of what think-aloud protocols provide and allow for more effective uses of this strategy in both instruction and assessment of writing narrative skill. In order to find the effect of think-aloud protocol on writing, the following questions were asked:

1. Is there any difference of thinking-aloud protocol on learners written narrative skill?

2. Which one is more effective to develop students' writing narrative skill by using think-aloud protocols and traditional method?

\section{METHOD}

\section{Participants}

The participants in this study were 60 students EFL students from SMA N 4 Metro, Lampung, Indonesia. Their ages ranged from 14 to 17, and they were all at beginner level. Population in this research is the eleventh grade of SMA N 4 Metro, Lampung. In this grade, there are five classes consist of 150 students which is divided into 30 students in each class .The researcher used cluster 
random sampling to takes the sample. Finally the researcher finds that XI IPS 1 and XI IPS 2 as the sample. XI IPS 1 as the experiment class and XI IPS 2 as the control class. The population is homogen in stratum, number of students and ability. Because the population is homogen in number and stratum, So the researcher would like to use cluster random sampling to get the sample reserach (Sugiyono, 2010). Bellow are the procedure to get the sample:

1) The whole students of eleventh grade.

2) The researcher writes each class in piece of paper.

3) The papers is rolled and then put into glass.

4) Then, the glass is shaken until getting rolling of paper out.

5) The first rolling of paper got to be the subject of the research as experiment class.

6) The second rolling of paper got to be the subject of the research as control class.

Finally, the researcher gets 2 classes as a sample. XI IPS 1 consist of 30 students as a experiment class and XI IPS 2 consist of 30 students as a control class. Total sample are 60 students.

\section{Instrument}

The task (See Appendix) used was a narrative based on pictures from Foster and Skehan (1996). This task is monologic rather than dialogic, it offers a basis for deriving measures of learner performance.

\section{Validity of the Instruments}

Content analysis and editing, the instruments were given to experts in the field of measurement and evaluation, language testing experts, Anwar Majid, S.Pd. as well as the researcher's supervisor for critical appraisal before administration.

\section{Reliability of Instruments}

The reliability coefficient was established before administration using the test retest method. In doing this, the instrument was personally administered to 60 students. The Pearson product moment correlation was used to determine the coefficient (r) 0.93 . 


\section{Procedure}

The goal of this study was to know whether there is differences of thinking-aloud protocol on developing writing skill. The researcher used a quasiexperimental research design with a sample of 60 students' of SMA N 4 Metro, Lampung. The data collection procedure consisted of three stages in two groups. Both groups had to write about the same topics. In Stage 1, students were asked to write about a topic. In Stage 2, students in the experimental group studied a model essay about that writing task and they think-aloud about those aspects of language that they noticed in the model essay. However in the control group, students studied model essays for themselves and they did not have think-aloud part. In Stage 3, students were asked to rewrite the writing task.

Below some aspects in narrative text that students can relate in their own words.

1. Orientation: an introduction in which the characters, setting and time of the story are established, usually answers who? When? Where?.

2. Complication or problem: the complication usually involves the main character.

3. Resolution: there needs to be resolution of the complication. The complication may be resolved for better or worse, happily or unhappliy. Sometimes there are a number of complications that have to be resolved. These add and sustain interest and suspense for the reader.

The post testing procedures were exactly the same as pretesting

\section{Design}

The researcher uses quasi experimental research. It uses two class in the prosses of taking the data. They are experimental class and control class. The experimental class gets treatments through think-aloud protocols and the control class gets treatment through traditional method. Each of classes receives pre-test, treatment and post-test in order to find the progress of students' writing narative text ability. There are two kinds of tests here used by researcher, they are pre-test and post-test. The pre-test distributed by the researcher before explaining the materials. Here, the researcher wants to know how far the students' writing narrative text before treatment. Then, the post-test will be distributed after explaining the materials. The treatment will be conducted for moreless two weeks. Therefore this research will be modified based on Setiyadi (2006) research design. 
Pre-test, treatment and post- test. It can be represented on the following design bellow.

This research design can be described as follows:

$\mathrm{T} 1 \mathrm{X} \mathrm{T} 2$

T1: Pre-test X: treatment T2: Post-test

(Setiyadi, 2006)

Table above describes the Pre-Test and Post-Test Control Group design. It used two classes in the prosses of taking the data. They were experimental class and control class. Each of classes receive pre-test, treatment and post test in order to find the progress of students' writing narrative text. The researcher uses pre-test and post-test to measure the result of students' writing narrative essay before and after the treatment.

The formula of hypothesis test:

(1)

$$
t \text { test }=\frac{x_{1}-x_{2}}{S_{\mathrm{g}} \sqrt{\frac{1}{n_{1}}+\frac{1}{n_{2}}}}
$$

$$
S_{g}=\frac{\left(n_{1}-1\right) S_{1}^{2}+\left(n_{2}-1\right) S_{2}}{n_{1}+n_{2}-2}
$$

Notes:

$\mathrm{X}_{1}=$ The arithmetical mean of experimental group

$\mathrm{X}_{2}=$ The arithmetical mean of control group

$\mathrm{n}_{1}=$ Number of students in experimental group

$\mathrm{n}_{2}=$ Number of students in control group

$\mathrm{S}_{1}=$ Standard devitation of experiment group

$\mathrm{S}_{2}=$ Standard devitation of control group

Bellow is the procedur of the data calculating:

(Sugiyono, 2010)

1) The researcher colect the data $X_{1}, X_{2}, N_{1}, N_{2}, S_{1}$, and $S_{2}$.

2) Next, $N_{1}, N_{2}, S_{1}$, and $S_{2}$ are included in $S_{\text {gab }}$ formula.

3) The result Score of $S_{\text {gab }}$ is included in $t_{\text {test }}$ formula.

4) The result score of test is check in t-table.

5) When $t_{\text {hit }}>t_{\text {table }}$ so hipotesis test is accepted.

The criteria of the test are:

$\mathrm{H}_{\mathrm{a}}=\mathrm{H}_{\mathrm{a}}$ is accepted if $\mathrm{T}_{-}$ratio is equal or higher than $\mathrm{t}_{-}$table. (The hypothesis proposed is proved)

$\mathrm{H}_{\mathrm{o}}=\mathrm{H}_{\mathrm{o}}$ is accepted if $\mathrm{t}_{-}$ratio is smaller than $\mathrm{t}_{-}$table. (The hypothesis proposed is not proved). 


\section{RESULT AND DISCUSSION}

\section{RESULT}

From the result of the research, it found that the mean score of experimental class who got think-aloud protocols in pre-test of experimental class is 56.12 and in post test 75.4. Meanwhile the mean score of the control group in pre-test of control class 49.5 and in post test is 72.4 . It means that there is a significant different of experimental and control class in students' writing narrative text, and students in the experimental class has higher score than in the control class in writing narrative text. To make students' writing narrative text improved, the teacher should use the think-aloud protocols in giving instructions or information about the material. It can help them in learning to write well, interest, and be active, so that their ability in writing can be improved.

The results show that there is a significant difference between two groups in the post-test. In the post-test, the experimental group outperforms the control group in the writing task. The descriptive statistics of students' noticing in the think-aloud protocol show that students notice vocabulary more than the other categories. Furthermore, the findings of this study are consistent with some of the previous L2 writing studies which include a comparison-stage of students' original writing and a model text (e.g., Hanaoka, 2006, 2007; Qi and Lapkin, 2001). The findings of these studies indicate that the participants noticed the lexical aspects far more frequently than the other three categories. The present study was an investigation into the way Iranian EFL learners handle a writing task. It employed think-aloud (TA) data collected from 40 participants. The findings of the present study also support that thinking-aloud and paying attention to different categories used in other peoples' writing (model essays) may improve writing.

The reason behind the positive effect of thinking-aloud is the learners' cognitive processing system and the factor noticing. In this study, students instead of imitating model essays, first, write about the task and recognize their problems in writing, then models are introduced and students try to solve their writing problems by studying a model essay and thinking-aloud about what they notice. 
The researcher suggests that think-aloud protocols is good to be practiced for students.

\section{DISCUSSION}

In this research, in the experiment and control class is treated for three meetings. The data which is described in this research are the data of the thinkaloud protocols as cognitive strategy to develop students' writing skill experiment class and control class. Based on the result of this research, the researcher finds that students' writing narrative text in the experimental class is good than in the control class. It can be proven that there are many students in the control class get fewer score in writing narrative text than in the experimental class. From the previous calculation, the hypothesis can be accepted because $t_{h i t}$ is 2.36 and $t_{\text {table }}$ is 1.99 on the criterion 1 and also table is 2.64 on the criterion 2 . In this case the researcher uses 0.05 or 1.99 . It shows that the hypothesis of $\mathrm{H}_{\mathrm{a}}$ is accepted and $\mathrm{H}_{\mathrm{o}}$ is rejected. It means that there is a significant difference between think-aloud protocols in writing narrative text for the eleventh grade students of SMA N 3 Metro and it also conclude that think-aloud protocols is more effective.

In the experiment class, before conducting the research, researcher met individually with each students to learn more about their feelings on writing. The following questions were used by the researcher during the meeting such as;

When you write, what do you think at the first time?;

What is the first thing that comes to your mind when you write a story?;

What kinds of strategies do you use when you write a story?;

Does it help you to write?

The researcher took notes on the students' responses in a notebook.

During treatment, the students was given a think-aloud protocol with some stories. First, the students was asked to look at a picture that they chose. Then, they tell about that story based on what was on their mind. Once, the story was complete the researcher asked the students to write down the story they just told.

After the students familiar with the think-aloud protocol, they began working on composing their written narrative. The student stated, "I am thinking about what I did last week." Then the researcher responses "What are you thinking of?"

In post-test, the students given some pictures that they were going to write. the students' were asked to tell about the picture, they can tell what was on their mind 
in a short-term memory, then they can write it down into a some paragraphs. So, there were some communication between the students and the researcher.

The researcher: what do you think of this picture?

The student: I think, it can happen to everyone. I think this is like me and my father at home.

The researcher: what did you do actually?

The student: I watched TV, then my TV had something trouble. So, I asked my father to fix it.

Then, the reseacher asked the student to write it down into a narrative paragraph.

From the discusion above, it can be said that there is a significant difference between think-aloud protocols with traditional technique in writing narrative text.

\section{CONCLUSION}

In this study, students instead of imitating model essays, first, write about the task and recognize their problems in writing, then models are introduced and students try to solve their writing problems by studying a model essay and thinking-aloud about what they notice. In this case, process and product are focused at the same time. The findings of this study can help language teachers improve their approaches to teach writing and raise students' ability. Think-aloud protocol is an effective way to teach students to promote their cognitve strategy. The authors suggest replications with other groups of language learners in different settings with different tasks or in spoken mode to come up with more comprehensive results.

\section{REFERENCES}

Davey, B. (1983).Think Aloud: modeling the cognitive processes of reading comprehension. Journal of Reading 27 44-47.

Ereiter, C, and Bird, M (1985).Use of thinking aloud in identification and teaching of reading comprehension strategies. Cognition and Instruction 2(2) 131156.

Hansen, LM And Johnson JC (2006). Think-Alouds in Inquiry Science. Science \& Children 44(1) 56. 
Hanaoka, O. (2006). Exploring the role of models in promoting noticing in L2 writing. JACET Bulletin 42 1-13.

Hanaoka, O. (2007). Output, noticing, and learning: An investigation into the role of spontaneous attention to form in a four-stage writing task. Language Teaching Research 11 459-479.

Kucan, L., and Beck IL (1997). Thinking aloud and reading comprehension research. Review of Educational Research 67(3) 271-299.

Kuusela, H., and, Paul, P. (2000). A comparison of concurrent and retrospective verbal protocol analysis.

Oster, L. (2001). Using the think-aloud for reading instruction. The Reading Teacher 55(1) 64-69.

Qi DS and Lapkin S ( 2001). Exploring the role of noticing in a three stage second language writing task. Journal of Second Language Writing 10(4) 277-303.

Schellings, G (2011). Applying learning strategy questionnaires: problems and possibilities. Metacognition Learning 6 91-109.

Setiyadi, Ag. Bambang. (2006). Metode Penelitian untuk Pengajaran Bahasa Asing. Yogyakarta: Graha Ilmu Publish.

Silva, T. and Matsuda, P. K. (2002). Writing. In Schmitt, N. (2002). An introduction to applied linguistics. (pp.251-266). New York: Oxford University Press Inc.

Sugiyono (2010). Metode Penelitian Pendidikan Pendekatan Kuantitatif, kualitatif, dan $R \& D$, Alfabeta., Bandung.

Schunk, HD (2004). Learning Theories (Pearson Publication Ltd).

Scott, DB (2008). Assessing text processing: A comparison of four methods. Journal of Literacy Research 40(3) 290-316. 